\title{
Expression of gus and gfp genes in amphidiploid spelt wheat (Triticum spelta L.) after Agrobacterium-mediated transformation
}

\author{
A. V. Kyriienko ${ }^{1,2^{*}}$, M. V. Kuchuk ${ }^{1}$, N. L. Shcherbak ${ }^{1}$, \\ M. F. Parii ${ }^{2,3}$, Yu. V. Symonenko ${ }^{1,2}$ \\ ${ }^{1}$ Institute of Cell Biology and Genetic Engineering, NAS of Ukraine, 148 Academika Zabolotnoho St., Kyiv, 03143, \\ Ukraine, *e-mail: anastasija.kirienko@gmail.com \\ ${ }^{2}$ Ukrainian Scientific Institute of Plant Breeding, 30 Vasylkivska St., Kyiv, 03143, Ukraine \\ ${ }^{3}$ National University of Life and Environmental Sciences of Ukraine, 15 Heroiv Oborony St., Kyiv, 03041, Ukraine
}

Purpose. To study the expression of gus and gfp genes in callus explants of amphidiploid spelt wheat (Triticum spelta L.) after Agrobacterium-mediated genetic transformation. Methods. Winter spelt wheat of 'Europa' variety was chosen for transformation. Calli obtained from mature embryos were used as explants. Callus pre-cultivation was carried out on MS nutrient medium (Murashige-Skoog) supplemented with $2 \mathrm{mg} / \mathrm{L}$ 2.4-D (2.4-Dichlorophenoxyacetic acid) and $10 \mathrm{mg} / \mathrm{L}$ silver nitrate. For genetic transformation, Agrobacterium tumefaciens Conn., strain GV3101 and a genetic construct with reporter genes beta-glucuronidase (GUS) and green fluorescent protein (GFP) were used. Calli were transformed by inoculation with agrobacteria and vacuum infiltration. Then they were co-cultured on MS medium with $2 \mathrm{mg} / \mathrm{L} \mathrm{2.4-D} \mathrm{and} 10 \mathrm{mg} / \mathrm{L} \mathrm{AgN03,} \mathrm{but}$ without antibiotics. The expression of the gus gene was checked by histochemical and the gfp gene by visual analysis (fluorescence of the GFP protein in UV light). Gfp and gus gene expression levels were evaluated using ImajeJ software. The integration of the $g f p$ and gus genes into the spelt genome was verified by PCR. Results. Genetic transformation of spelt callus explants by inoculation in a nutrient medium with agrobacteria and vacuum infiltration occurred at different frequencies. The level of expression of the gus gene during vacuum infiltration was $4.66 \pm 0.74 \%$, with inoculation $-4.00 \pm 0.91 \%$; and the $g f p$ gene with vacuum infiltration $-3.66 \pm 0.74 \%$, with inoculation $-4.66 \pm 1.39 \%$. The level of expression of the $g f p$ gene was higher when using inoculation with agrobacteria, and the gus gene was higher during vacuum infiltration. Using PCR analysis, the integration of the $g f p$ and gus genes into the callus of spelt genome was confirmed. The length of the PCR product with primers for the gus gene was $240 \mathrm{bp}$, and $717 \mathrm{bp}$ for the $\mathrm{gfp}$ gene. Conclusions. The use of vacuum infiltration and inoculation methods for spelt genetic transformation gave different results. The frequency of genetic transformation ranged from 3.66 to $4.66 \%$. Agrobacterium-mediated genetic transformation of amphidiploid spelt wheat allows us to study the expression of gus and $g f p$ reporter genes using callus explants derived from mature embryos.

Keywods: Triticum spelta L.; spelt; callusogenesis; gus gene; gfp gene; genetic transformation.

\section{Introduction}

Various forms of amphidiploid wheat are used for creating their new varieties and lines with maximum manifestation of economically valuable traits. Such signs include the total mass of 1000 grains, the height of the plants, its lodging resistance, high protein content in a grain, resistance to diseases and pest damage, and so forth. Now in the world there is a depletion of the gene pool of amphidiploid wheat. It is associated with the use of many

Anastasiia Kyriienko

https://orcid.org/0000-0002-8117-5288

Nikolay Kuchuk

https://orcid.org/0000-0001-7365-7474

Natalia Shcherbak

https://orcid.org/0000-0002-2478-8408

Myroslav Parii

https://orcid.org/0000-0001-9877-2241

Yuri Symonenko

https://orcid.org/0000-0002-5597-3315 genotypes resemble each other in the work. In addition, virtually every decade new strains of pathogens of plant infectious diseases appear and climatic conditions change.

Traditional breeding does not always have time to satisfy the needs of society, and sometimes it is simply impossible. Therefore, it is advisable to resort to other methods of obtaining new forms of amphidiploid wheat. Such new methods include the genetic transformation of plants, which can be either direct or indirect. Direct genetic transformation occurs during the biolistic transformation when plasmid DNA is delivered into plant explants by high velocity gold or tungsten particles [1]. Indirect transformation occurs with the participation of the corresponding strain of agrobacteria and is a fairly common method [2]. Agrobacterium-mediated transformation can occur by inoculating explants with agrobacteria in a liquid nutrient medium for a certain time, during which agrobacteria gradually penetrate explant tissues [2-4] or by vacuum 
infiltration - when under special conditions pressure difference is created between the closed chamber and the environment, allowing agrobacteria to penetrate into tissues $[5,6]$.

An important step in the study is the selection of the working strain of Agrobacterium tumefaciens Conn. From literary sources it is known that for genetic transformation strains EHA105 [7], AGL-1 [2, 8-10], GV3101 [11], LBA4404 [2] and others are used. Usually, an overnight culture of agrobacteria grown in a liquid nutrient medium LB (Luria-Bertani) at a temperature of $28{ }^{\circ} \mathrm{C}$ is used $[10,12]$. The explants for genetic transformation of amphidiploid wheat can be both mature $[10,13]$ and immature embryos $[8,14]$. Before transformation, explants are recultivated on a nutrient medium MS with auxin. For soft wheat, 2.4-D is better suited at a concentration of $2-4 \mathrm{mg} / \mathrm{L}[2,13,15]$. Usually, precultivation takes place in the darkness and can last several days $[2,16]$. It depends on the characteristics of the selected wheat genotype and on the cultivation conditions (temperature, relative humidity, composition of the nutrient medium, etc.).

Genetic transformation of callus explants is usually carried out by immersing them in a suspension of the corresponding strain of agrobacteria in a liquid nutrient medium. For operation, the agrobacterial suspension should be of a certain concentration; its $\mathrm{OD}_{600}$ depends on the selected working strain, the composition of the culture medium and can vary from 0.4 to 3 [2, 14, 17, 18].

During inoculation, agrobacteria together with explants are introduced into the liquid inoculation medium, whose composition can correspond to or close to the MS medium [18, 19] and contain growth regulators [17]. We know that in order to improve the positive chemotaxis of agrobacteria, phenolic compounds, in particular acetosyringone at a concentration of $200-400 \mathrm{mmol}$, can be added to their suspension $[14,20]$. Inoculation can last from 15 minutes to several hours, depending on the type of explant. For freshly isolated immature embryos of amphidiploid wheat, it can last up to 3 hours at a temperature of $23-25{ }^{\circ} \mathrm{C}$, but for recultivated immature embryos - up to 1 hour, and for embryogenic callus - up to several hours [2].

After inoculation in a nutrient medium with agrobacteria, plant explants are transferred to a medium without antibiotics and silver nitrate in darkness for several days for co-cultivation. Then they are washed from agrobacteria in an antibiotic solution, for example, cef- triaxone or timentin $[2,16]$, and the washed callus explants are transferred to a nutrient medium containing a selective agent for regeneration. Most often, selective substances can be herbicides - phosphinotricin $[2,17]$ or glyphosate [21]. The choice of selective agent depends on the transferred resistance gene, which is integrated into the plant genome during transformation. Thus, phosphinotricin is used for bar gene (phosphinotricin $\mathrm{N}$-acetyltransferase) [22], and glyphosate for epsps gene (5-enolpyruvylshikimate-3-phosphate synthase) [21]. For the selection of transformants, in addition to selective genes, reporter genes are also used, for example, the gfp gene. The product of its expression exhibits green fluorescence upon ultraviolet irradiation (UV) [23, 24]. Another marker reporter gene is the gus gene. The product of its expression during histochemical reaction of interaction with $\mathrm{X}$-Gluc (5-bromo-4-chloro-1H-indol-3-yl $\beta$-D-glucopyranosiduronic acid) stains transformant tissues in blue color [4].

The $\mathrm{pH}$ of the inoculation medium, concentration of acetosyringone and temperature are important for further plant regeneration. It was shown that at pH 5.8 and $200 \mu \mathrm{m}$ of acetosyringone in a medium at a temperature of $22{ }^{\circ} \mathrm{C}$, the regeneration frequency of transformed wheat explants was about $10.5 \%$, but at $\mathrm{pH} 5.0,200 \mu \mathrm{m}$ of acetosyringone and a temperature of $22{ }^{\circ} \mathrm{C}$, the frequency reached $22.3 \%$. At a concentration of $400 \mu \mathrm{m}$ of acetosyringone, $\mathrm{pH} 5.0$ and a temperature of $19{ }^{\circ} \mathrm{C}$, the regeneration frequency increased to $30.3 \%$ [20].

Spelt (T. spelta L.) is a rare species of amphidiploid wheat. Unlike common wheat, there is no information about its genetic transformation in order to obtain new transgenic lines. The novelty of our work was the presentation of data on the genetic transformation of callus explants of spelt obtained from mature embryos.

The purpose of the study was to reveal the expression of gus and gfp genes in callus explants of spelt amphidiploid wheat (T. spelta L.) after Agrobacterium-mediated genetic transformation.

\section{Materials and methods}

We used seeds of winter amphidiploid spelt wheat ( $T$. spelta) of 'Europa' variety $(2 n=42)$, which was provided by Ukrainian Scientific Institute of Plant Breeding (VNIS). It was precisely this spelt genotype that was chosen for the genetic transformation, because variety 'Europa' best demonstrates itself in an in vitro 
culture as previous studies have shown [25]. Mature embryos were used as explants for introduction into in vitro culture. Seeds were sterilized in $96 \%$ ethanol for $5 \mathrm{~min}$, then in a $5 \%$ solution of sodium hypochlorite for 10 min and washed three times with sterile distilled water.

Callus induction was performed on standard MS medium [19] with a 3\% maltose content (Duchefa Biochemie, Netherlands) supplemented with $2.5 \mathrm{mg} / \mathrm{L}$ 2,4-D (Duchefa Biochemie, Netherlands), $10 \mathrm{mg} / \mathrm{L}$ of silver nitrate and $300 \mathrm{mg} / \mathrm{L}$ of ceftriaxone (Arterium, Ukraine), which was added to the medium in such a concentration to prevent bacterial contamination. Explants were cultured in the darkness at a temperature of $24^{\circ} \mathrm{C}$ for 14 days.

An overnight culture of Agrobacterium tumefaciens Conn., strain GV3101, was used for the genetic transformation of callus explants. Agrobacteria were grown in liquid nutrient medium LB [12] with the addition of antibiotics $(50 \mathrm{mg} / \mathrm{L}$ rifampicin ("Borschagovsky CPP", Ukraine), $100 \mathrm{mg} / \mathrm{L}$ kanamycin ("Arterium”, Ukraine) and $25 \mathrm{mg} / \mathrm{L}$ gentamicin (“Ar- terium", Ukraine) at a temperature of $28{ }^{\circ} \mathrm{C}$. The final optical density of agrobacteria was brought to $\mathrm{OD}_{600}=\mathbf{0 . 8}$.

For the genetic transformation of callus explants, the pSPN2401 genetic construct was used, which contained two reporter genes: the gfp gene isolated from Aequorea victoria Marbach \& Shearer, under the control of the promoter of the lhb gene encoding chlorophyll $a-b$ binding proteins (LHCB) isolated from thale cress [Arabidopsis thaliana (L.) Heynh.], and the gus gene under the control of the promoter of the $r b c$ gene encoding the small subunit of ribulose bisphosphate carboxylase ( $\mathrm{Ru}-$ BisCo), also isolated from A. thaliana (L.) Heynh. Both genes were controlled by the 35S cauliflower mosaic virus terminator (CaMV) along with a polyadenylation signal and a 3'-untranslated sequence. In addition, both transcriptional units contained a 5'-untranslated sequence $\Omega$ (UTR) from the tobacco mosaic virus (TMV) (Fig. 1). The gfp gene encodes the green fluorescent protein (GFP), and the product of the gus gene activity is $\beta$-glucuronidase enzyme.

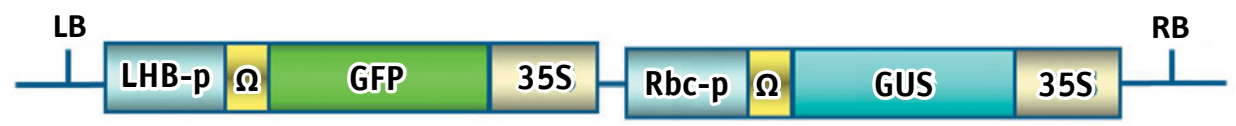

Fig. 1. Structural elements of the T-DNA vector pSPN2401 for the genetic transformation of spelt callus explants

The genetic transformation of callus spelt explants was performed by inoculation with agrobacterium suspension and vacuum infiltration. The results for both types of transformation were compared among themselves. In the first case, a nutrient medium similar to callusogeneses was used for inoculation with the addition of $40 \mathrm{mg} / \mathrm{L}$ acetosyringone. Callus explants were cultured with agrobacterium suspension in the darkness at $24{ }^{\circ} \mathrm{C}$ for 2 hours. Co-cultivation was performed in MS nutrient medium for callusogeneses, but without antibiotics and silver nitrate, in the darkness for 3 days. Then calli were transferred to the medium with an antibiotic and cultured in the darkness for another 5 days.

In the case of vacuum infiltration, callus explants were introduced into a liquid nutrient medium with agrobacteria, similar in composition to the inoculation medium. To do this, we used a glass desiccator with polished edges ( $2 \mathrm{~L}$ volume) with a hose attached to a pump that pumped air out of it creating vacuum conditions. Inside the desiccator cups with a liquid nutrient medium with callus explants and agrobacterium suspension were placed.
The desiccator was tightly closed and air was pumped out of it. Infiltration was performed in two stages, each lasting 10 minutes at 0.6 atmospheres. The co-cultivation conditions were similar to precultivation.

To eliminate agrobacteria, callus explants were washed with a solution of antibiotic ceftriaxone at a concentration of $300 \mathrm{mg} / \mathrm{L}$.

The frequency of genetic transformation of spelt callus explants was determined after 5 days. To identify gfp gene expression product, the transformed callus was irradiated with ultraviolet light and green calli, in which the expression of the gfp gene was observed, were counted. To analyze the level of gus gene expression in callus explants, a histochemical analysis of $\beta$-glucuronidase gene expression was performed according to the Jefferson method (1987) [26] in $100 \mathrm{mM}$ phosphate buffer pH 7.0 containing $1 \mathrm{mM}$ $\mathrm{X}$-Gluc. On the 6 th day after the transformation, callus fragments were incubated for 24 hours in a $1 \mathrm{mM}$ X-Gluc solution at a temperature of $37{ }^{\circ} \mathrm{C}$, followed by washing in a $70 \%$ ethanol solution also at $37{ }^{\circ} \mathrm{C}$ for up to 48 hours. 
The expression level of gus and gfp genes was estimated. It manifested itself as a blue color or a bright green glow in ultraviolet light, respectively, using the ImajeJ program [27]. The transformed callus explants were photographed, the images were processed in the ImajeJ resource, as a result gene expression sites in the tissues obtained a gray color of various intensities. After measuring the gray color intensity, an appropriate graph was obtained. The level of gray color intensity corresponded to the level of gus and $g f p$ genes expression. The higher the gray intensity was in the image, the higher the expression level of the gus and $g f p$ genes was in the cells (Fig. 2).

30 days after the genetic transformation, the total plant DNA was isolated from the samples of transformed calli with expression
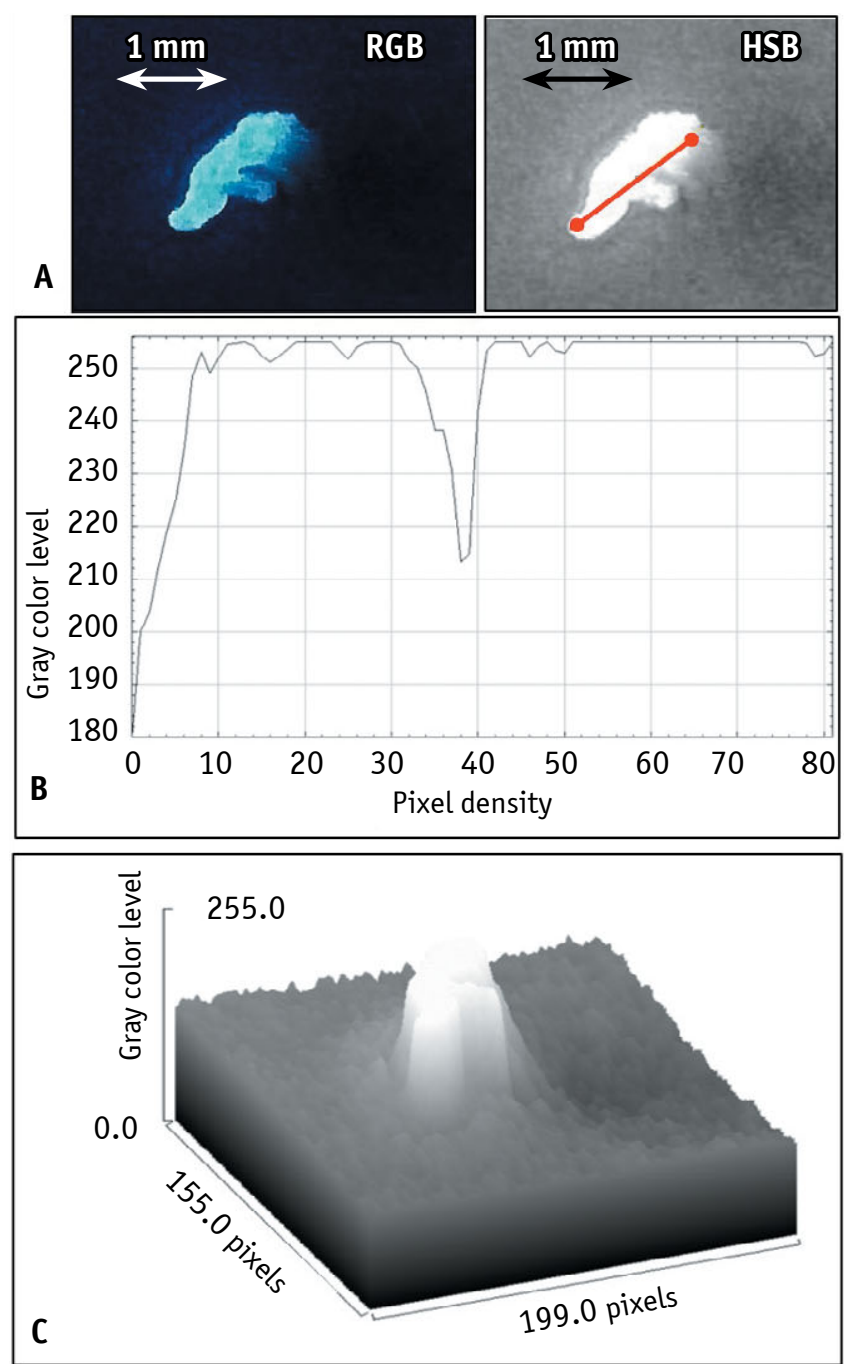

of the gfp and gus genes by the CTAB method (cetyltrimethylammonium bromide) [28]. The concentration of extracted DNA was determined by spectrophotometric method $\left(\mathrm{mQ} \mathrm{H}_{2} \mathrm{O}\right.$ was taken as a negative control). PCR reaction was performed with primers specific for the gus and gfp genes. So, for the gus gene, the following primer sequence was used: GUS-F ATGGGTCAGTCCCTTATGTTA, GUS-R ATAAAGACTTCGCGCTGAT; and for the $g f p$ gene it was GFP-F GTGAGCAAGGGCGAGGA, GFP-R - TTACTTGTACAGCTCGTCCAT. Primer sequences were selected using the NCBI BLAST online resource (blast.ncbi.nlm. nih.gov).

PCR amplification products were separated on a 1\% agarose gel. As a molecular length marker, 3 Kb DNA Ladder M25 ("Sib Enzyme”,
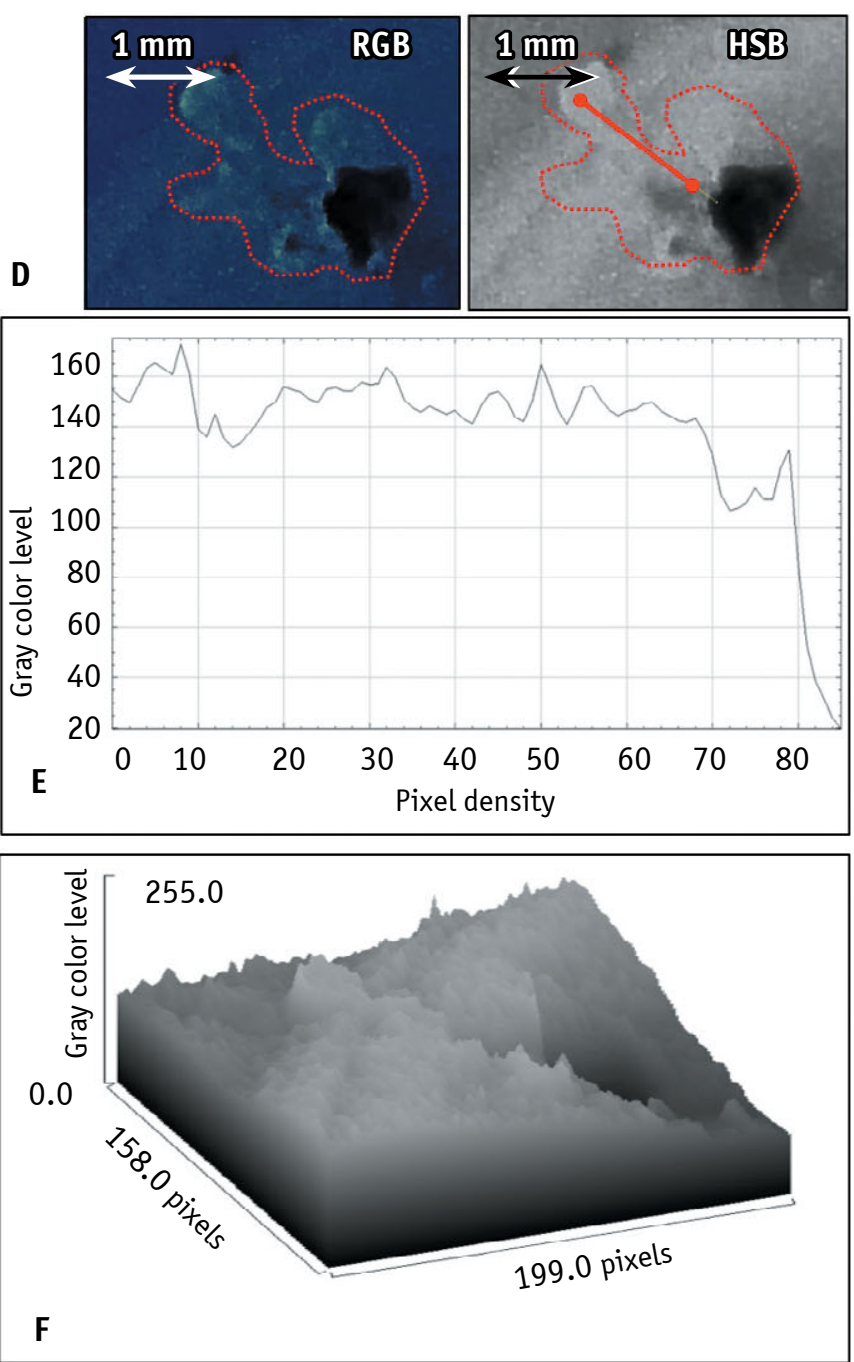

Fig. 2. Assessment of $g f p$ gene expression level in callus spelt explants with high (A-C) and low (D-F) expression levels (ImajeJ program):

A) and $D)-$ «RGB» and «HSB» image of callus explants, with high (A) and low (D) level of expression of the gfp gene (the red line indicates the area for measuring the intensity level, the red dotted line indicates callus for better orientation); $B$ ) and $\mathrm{E}$ ) are the graphs of the level of gray color intensity corresponding to green glow at gfp gene expression; $C$ ) and F) -

3-D models of the ratio of various shades of gray color for callus with high and low level of expression, respectively 
RF) was used. For PCR, a reaction mixture with a total volume of $20 \mathrm{ml}$ was taken, which contained $10^{\mathrm{x}}$ PCR buffer (100 mM Tris-HCl, $\mathrm{pH}$ 8.8, $500 \mathrm{mM} \mathrm{KCl,} 1 \%$ Triton X-100); $1.5 \mathrm{mmol} \mathrm{MgCl}_{2}$ ("Thermo Fisher Scientific", USA); $0.2 \mathrm{mmol}$ of each dNTP ("Thermo Fisher Scientific", USA); a pair of appropriate primers, each at a concentration of $12.59 \mathrm{pmol}$; Taq polymerase at a concentration of $1 \mathrm{U}$ ("Sib Enzyme", RF). The concentration of plant DNA in the PCR mixture was $100 \mathrm{ng}$. Plasmid DNA was used as a positive control, and $\mathrm{H}_{2} \mathrm{O}$ for a negative control.

Since we worked with two reporter genes and according to two transformation techniques, 4 groups of experiments were identified - gus: infiltration, gus: inoculation, gfp: infiltration and $g f p$ : inoculation. Each group consisted of 5 replicates of 60 callus explants each. The total amount of explants in the group was 300 pieces.

The frequency of genetic transformation was determined by the formula, which was taken and adapted from Gouranga et al. [29]: $(\mathrm{T} / \mathrm{E}) \times 100$, where $\mathrm{T}$ is the number of calli where the product of the expression of corresponding genes was detected, $\mathrm{E}$ is the total number of callus explants used for genetic transformation.

\section{Results and discussion}

After the genetic transformation of spelt callus explants by inoculation with agrobacteria, after 8 days, the expression of the gus and gfp genes was observed, which can be both transient and stable. According to visual ob-
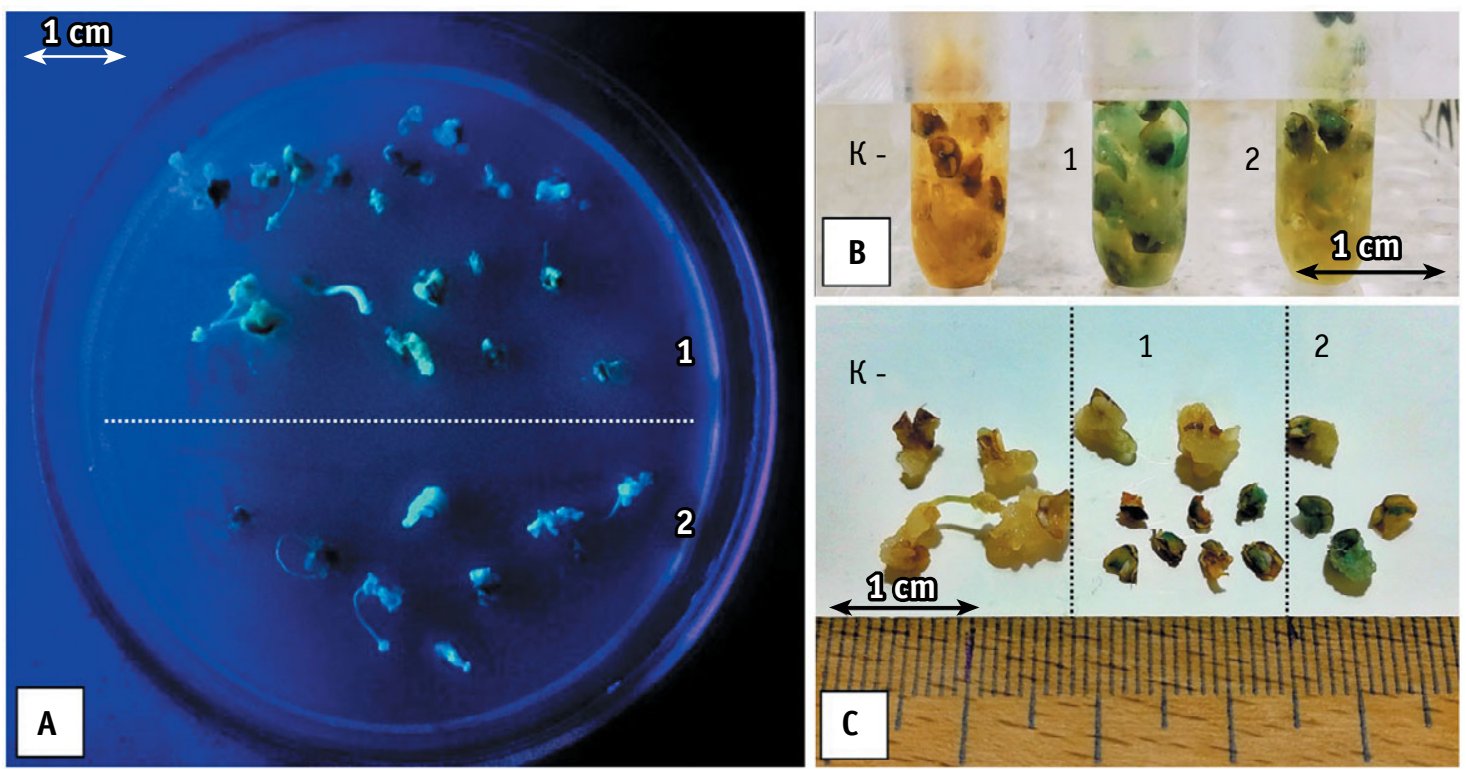

Fig. 3. Detection of $g f p$ and gus gene expression in spelt callus explants:

A) gfp gene expression in 20-day spelt calli on the 6th day after genetic transformation (1 - inoculation with agrobacteria, 2 - vacuum infiltration); B) and C) gus gene expression in 20-day (B) and 30-day (C) calli on the 7th day after genetic transformation ("K-" - negative control, untransformed calli, 1 - vacuum infiltration; 2 - inoculation with agrobacteria)

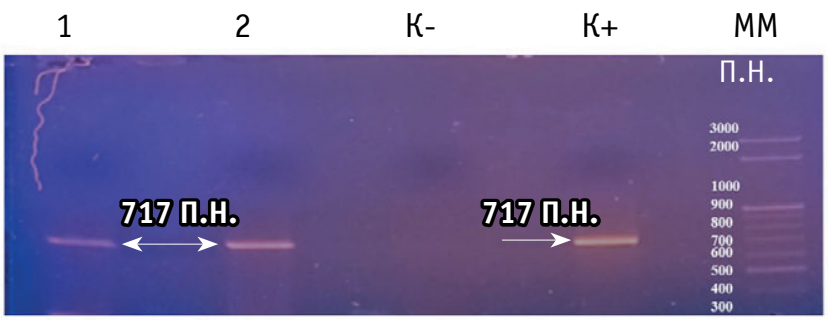

Fig. 4. The electrophoregram of amplification products of total plant DNA of spelt transformants ( $g f p$ genespecific primers):

1) DNA of transformant after inoculation with agrobacteria,

2) DNA of transformant after vacuum infiltration,

"K-" - negative control $\left(\mathrm{H}_{2} \mathrm{O}\right)$, ' $\mathrm{K}+$ ' - positive control (genetic construct pSPN2401) servations, the expression of the $g f p$ gene in the cells of callus explants was detected on the fifth day after their transformation. Under ultraviolet light, the calli with observed gene expression glowed bright green color (Fig. 3A).

The luminescence could be either pointed, where expression was observed only in separate callus cells, or complete - the entire explants glowed. The frequency of genetic transformation for the gfp gene in the case of inoculation with agrobacteria was $4.66 \pm 1.39 \%$ (Table 1).

In the case of bombarding of immature embryos of 'AvocetYr10' soft wheat variety with gold particles containing a genetic construct 
Frequency of genetic transformation of callus explants of wheat variety 'Europa'

\begin{tabular}{|c|c|c|c|c|c|}
\hline $\begin{array}{l}\text { Reporter gene / variant } \\
\text { of genetic transformation }\end{array}$ & Repeat & $\begin{array}{l}\text { Number of callus } \\
\text { explants (pcs.) }\end{array}$ & $\begin{array}{l}\text { Number of calli with reporter } \\
\text { gene expression (pcs.) }\end{array}$ & $\begin{array}{l}\text { Transformation } \\
\text { frequency (\%) }\end{array}$ & $\begin{array}{c}\text { Average frequency of } \\
\text { transformation }(\%), X \pm S\end{array}$ \\
\hline \multirow{5}{*}{ gus / infiltration } & 1 & 60 & 3 & 5.00 & \multirow{5}{*}{$4.66 \pm 0.74$} \\
\hline & 2 & 60 & 2 & 3.33 & \\
\hline & 3 & 60 & 3 & 5.00 & \\
\hline & 4 & 60 & 3 & 5.00 & \\
\hline & 5 & 60 & 3 & 5.00 & \\
\hline \multirow{5}{*}{ gus / inoculations } & 1 & 60 & 2 & 3.33 & \multirow{5}{*}{$4.00 \pm 0.91$} \\
\hline & 2 & 60 & 3 & 5.00 & \\
\hline & 3 & 60 & 3 & 5.00 & \\
\hline & 4 & 60 & 2 & 3.33 & \\
\hline & 5 & 60 & 2 & 3.33 & \\
\hline \multirow{5}{*}{$g f p$ / infiltration } & 1 & 60 & 2 & 3.33 & \multirow{5}{*}{$3.66 \pm 0.74$} \\
\hline & 2 & 60 & 2 & 3.33 & \\
\hline & 3 & 60 & 3 & 5.00 & \\
\hline & 4 & 60 & 2 & 3.33 & \\
\hline & 5 & 60 & 2 & 3.33 & \\
\hline \multirow{5}{*}{ gfp / inoculations } & 1 & 60 & 2 & 3.33 & \multirow{5}{*}{$4.66 \pm 1.39$} \\
\hline & 2 & 60 & 3 & 5.00 & \\
\hline & 3 & 60 & 4 & 6.66 & \\
\hline & 4 & 60 & 2 & 3.33 & \\
\hline & 5 & 60 & 3 & 5.00 & \\
\hline
\end{tabular}

Note. $X$ - average value, $S$ - sampling mean error.

with the $g f p$ reporter gene, Kronbak et al. [30] visually noted the transient expression of the gfp gene in soft wheat endosperm. For comparison, it is known that the frequency of stable genetic transformation using constructs containing selective genes for the selection of transgenic wheat lines on the corresponding selective media of 14-day embryogenic calli of amphidiploid spring wheat by inoculation with agrobacteria it was $1.2-3.9 \%$, and sometimes it reached $5.9 \%$ [2]. As noted by Dale et al. [5], if vacuum infiltration is performed with 6 approaches with a total duration of 1 hour, the frequency of genetic transformation may be about $8 \%$.

In our experiments during vacuum infiltration, the frequency of genetic transformation, based on the results on the gfp gene, was slightly lower than during inoculation, i.e. $3.66 \pm 0.74 \%$. At the same time, the fluorescence intensity of the GFP protein in callus explants was also less than in the previous variant. In particular, to assess the level of gfp gene expression after inoculation with agrobacteria, the level of gray color intensity was in the range of 210-255, and the value of 100-250 prevailed for vacuum infiltration. An example of assessing the level of $g f p$ gene expression in callus explants of spelt with high and low expression levels is presented in Fig. 2.

Further PCR analysis with primers specific to the $g f p$ gene was performed. It showed the integration of the $g f p$ gene into the genome of callus explants from mature spelt embryos both in the case of their genetic transformation by inoculation and vacuum infiltration (Fig. 4). According to the results of the analysis, a PCR product of about $717 \mathrm{bp}$ was detected, which corresponded to the expected size of the gfp gene [23]

Thus, the expression of the gus gene in callus explants using inoculation with agrobacteria was $4.00 \pm 0.91 \%$. But in the case of vacuum infiltration, it was slightly higher $-4.66 \pm 0.74 \%$ (Table 1). As noted by Dattgonde et al. [6], in the case of vacuum infiltration of mature embryos of common oat (Avena sativa L.), the gus gene genetic transformation frequency according to the results of histochemical analysis was $11-21 \%$.

For comparison, it is known that genetic transformation by inoculation of immature embryos of amphidiploid wheat of the 'Bobwhite' variety with agrobacteria containing a genetic construct with the gus gene gives up to $76 \%$ of transient expression [18]. This occurs in the presence of acetosyringone at a concentration of $40 \mathrm{mg} / \mathrm{L}$. If the transformation is performed without acetosyringone, the number of explants with gus gene expression will be at the level of $52 \%$ as Wu et al. [18] note.

The expression of the gus gene in callus explant tissues during histochemical analysis of $\beta$-glucuronidase expression was detected at different levels of intensity (after reaction with X-Gluc callus tissues obtained a blue color of different intensity) (Fig. 3B, 3C). It 
could cover either all callus cells, or could be observed only in separate cells. An example of estimating the level of gus gene expression in high- and low-expression spelt callus explants is presented in Figures 5.

The level of gray color intensity for the two variants of genetic transformation was slightly different. When using vacuum infiltration, the intensity was higher and varied in the range of $0-250$ values (mainly staying in the range of 160-250). But during inoculation, the level of gray color intensity rarely exceeded the value of 160 and mostly kept within values from 130 to 160 .

Further PCR analysis with primers specific to the gus gene was performed. It showed the integration of the gus gene into the genome of callus explants from mature spelt embryos both in the case of their genetic transformation by inoculation and vacuum infiltration (Fig. 6). PCR analysis with primers specific to the gus gene revealed an amplicon of about $240 \mathrm{bp}$, which corresponds to the expected size of the gus gene and was also about 240 bp [31].

Thus, for the first time the expression of the gus and gfp genes in callus explants of spelt ( $T$. spelta L.) after genetic transformation by vacuum infiltration and inoculation with agrobacteria is shown. The average frequency of genetic transformation using both techniques was slightly different. So, for the gus reporter gene, vacuum infiltration was more effective than inoculation $(4.66 \%$ and $4.00 \%$, respectively). And for the $g f p$ gene, a higher frequency of genetic transformation
A
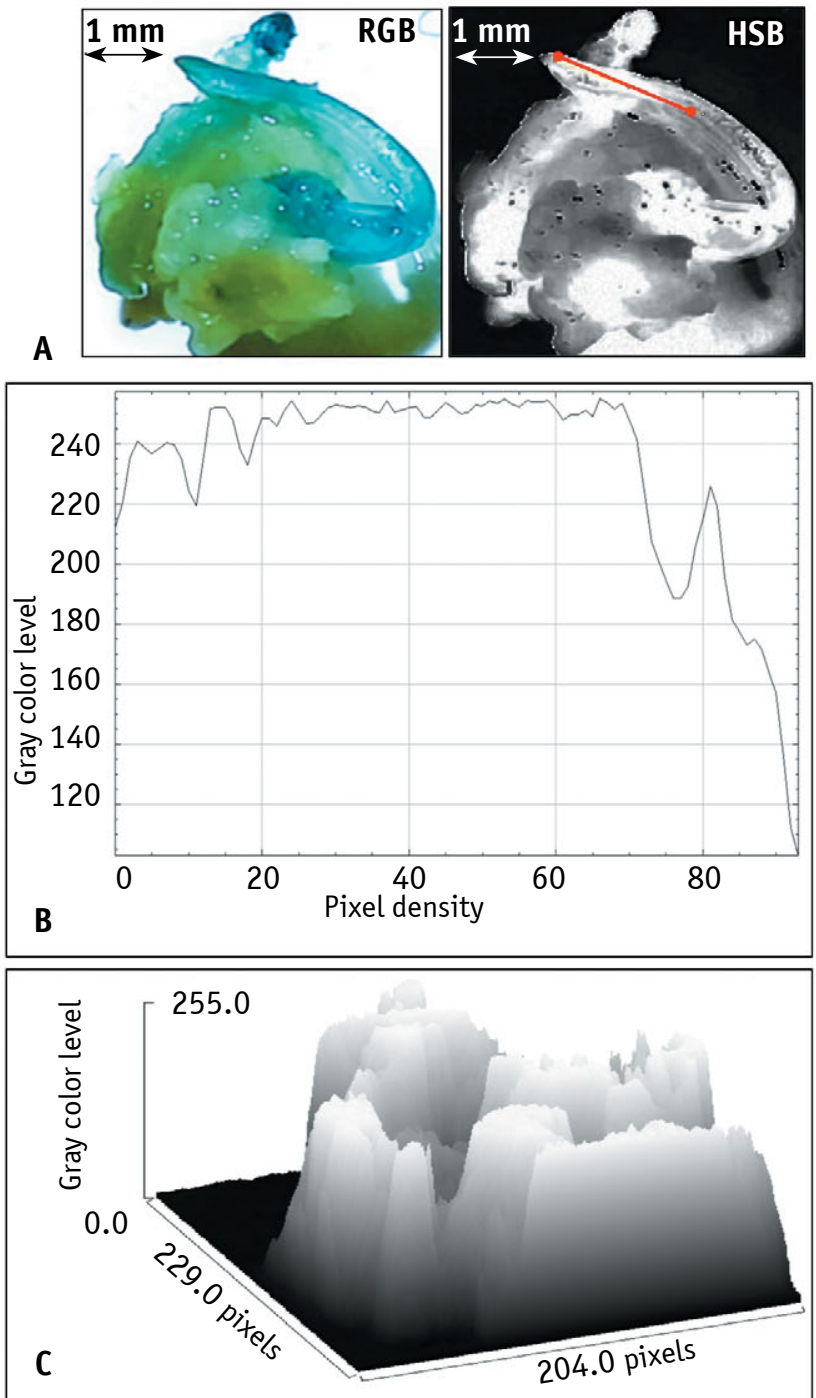
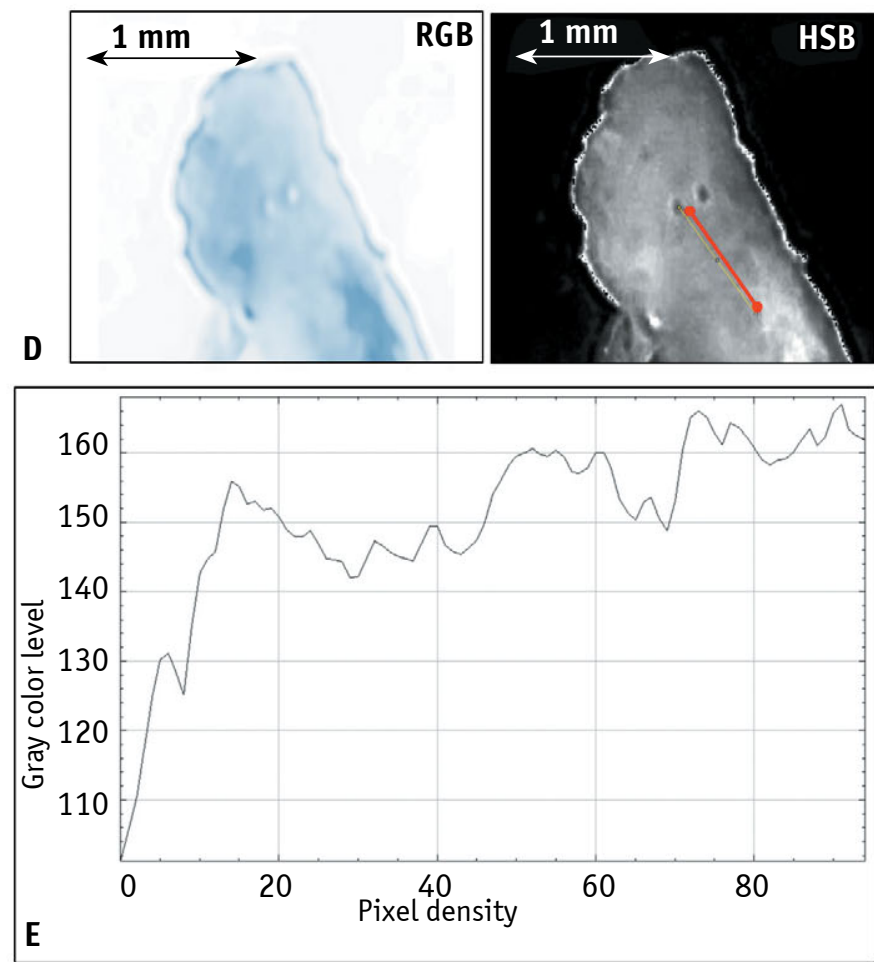

E

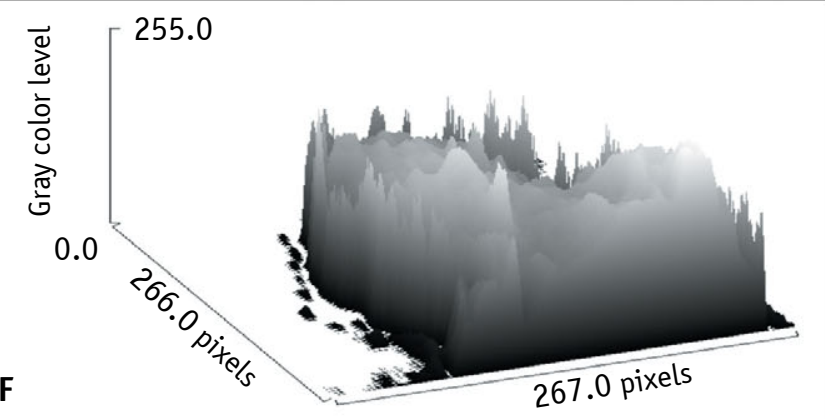

Fig. 5. Assessment of the gus gene expression level in callus spelt explants with high (A-C) and low (D-F) expression levels (ImajeJ program): A) and D) - «RGB» and «HSB» image of callus explants, with high (A) and low (D) level of the gus gene expression (the red line indicates the area for measuring the level of intensity); B) and E) - graphs of the intensity level of gray color, corresponding to the blue color in the gus gene expressing; C) and F) - 3-D models of the ratio of various shades of gray color for callus with a high and low level of expression, respectively 


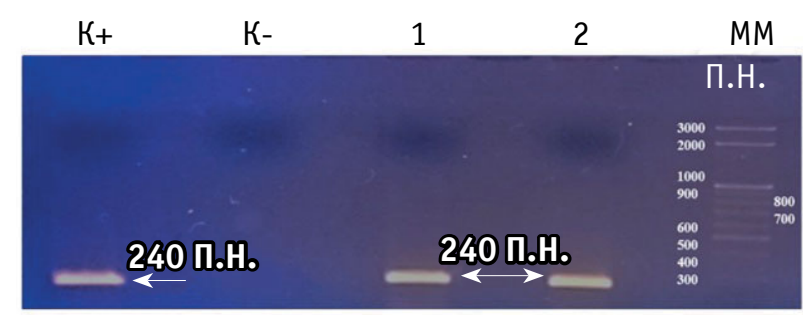

Fig. 6. The electrophoregram of amplification products of total plant DNA of spelt transformants (gus genespecific primers): 1) DNA of transformant after

inoculation with agrobacteria, 2) DNA of transformant after vacuum infiltration, "K-" - negative control $\left(\mathrm{H}_{2} \mathrm{O}\right)$, "K+" positive control (genetic construct pSPN2401)

was during inoculation than vacuum infiltration $(4.66 \%$ and $3.66 \%$, respectively). In our experiments, the expression of the gus and gfp reporter genes could be both temporary (transient) and stable.

\section{Conclusions}

The expression of the gus and gfp genes in callus explants of spelt (T. spelta L.) after genetic transformation by vacuum infiltration and inoculation with agrobacteria was shown for the first time. The use of vacuum infiltration and inoculation methods for the genetic transformation of spelt gave different results. In general, the frequency of genetic transformation of callus explants from mature embryos of 'Europa' variety spelt by the gfp gene in the case of inoculation was $4.66 \pm 1.39 \%$. And for vacuum infiltration it was at the level of $3.66 \pm 0.74 \%$. The frequency of genetic transformation of the gus gene during vacuum infiltration was about $4.66 \pm 0.74 \%$, and by inoculation with agrobacteria $-4.00 \pm 0.91 \%$. PCR analysis showed the presence of two reporter genes gus and gfp in the callus of spelt (the length of the PCR product with primers for the gus gene was $240 \mathrm{bp}$, and for the $g f p$ gene - $717 \mathrm{bp}$ ). Agrobacterium-mediated genetic transformation of amphidiploid spelt wheat (T. spelta L.) allows studying the expression of the gus and gfp reporter genes using callus explants derived from mature embryos.

\section{Acknowledgments}

The work was carried out within the framework of the fundamental departmental theme of the Department of Genetic Engineering, ICBGE NAS of Ukraine: III-8-17 "Studying the functioning of heterologous genes and their influence on the adaptive properties of plant systems under biotic and abiotic stresses" (state registration number 0117U002589, 2017-2021).

\section{References}

1. Hamada, H., Liu, Y., Nagira, Y., Miki, R., Taoka, N., \& Imai, R. (2018). Biolistic-delivery-based transient CRISPR/Cas9 expression enables in planta genome editing in wheat. Sci. Rep. 8, 14422. doi: 10.1038/s41598-018-32714-6

2. Jones, H. D., Duherty, A., \& Wu, H. (2005). Review of methodologies and a protocol for the Agrobacterium-mediated transformation of wheat. Plant Methods, 1, 5. doi: 10.1186/17464811-1-5

3. Wu, H., Doherty, A., \& Jones, H. D. (2008). Efficient and rapid Agrobacterium-mediated genetic transformation of durum wheat (Triticum turgidum L. var. durum) using additional virulence gens. Transgenic Res., 17(3), 425-436. doi: 10.1007/ s11248-007-9116-9

4. Hayta, S., Smedley, M. A., Demir, S. U., Blundell, R., Hinchliffe, A., Atkinson, N., \& Harwood, W. A. (2019). An efficient and reproducible Agrobacterium-mediated transformation method for hexaploid wheat (Triticum aestivum L.). Plant Methods, 26, 121. doi: 10.1186/s13007-019-0503-z

5. Dale, P. J., Marks, M. S., Brown, M. M., Woolston, C. J., Gunn, H. V., Mullineaux, P. M., ... Flavella, R. B. (1989). Agroinfection of wheat: inoculation of in vitro grown seedlings and embryos. Plant Sci., 63(2), 237-245. doi: 10.1016/0168-9452(89)90249-5

6. Dattgonde, N., Tiwari, S., Sapre, S., \& Gontia-Mishra, I. (2019). Genetic transformation of oat mediated by Agrobacterium is enhanced with sonication and vacuum infiltration Iranian. Iran J. Biotechnol., 17(1), e1563. doi: 10.21859/ijb.1563

7. Kumar, R., Mamrutha, H. M., Kaur, A., Venkatesh, K., Sharma, D., \& Singh, G. P. (2019). Optimization of Agrobacterium transformation in spring bread wheat using mature and immature embryos. Mol. Biol. Rep., 46(2), 1845-1853. doi: 10.1007/s11033019-04637-6

8. Hensel, G., Marthe, C., \& Kumlehn, J. (2017). Agrobactrium-mediated transformation of wheat using immature embryos. Methods Mol. Biol., 1679, 129-131. doi: 10.1007/978-1-49397337-8_8

9. He, Y., Jones, H. D., Chen, S., Chen, X. M., Wang, D. W., Li, K. X., Wang, D. S., \& Xia, L. Q. (2010). Agrobacterium-mediated transformation of durum wheat (Triticum turgidum L. var. durum $\mathrm{cv}$ Stewart) with improved efficiency. J. Exp. Bot., 61(6), 15671581. doi: $10.1093 / \mathrm{jxb} / \mathrm{erq} 035$

10. Medvecká, E., \& Harwood, W. A. (2015). Wheat (Triticum aestivum L.) transformation using mature embryos. Methods Mol. Biol., 1223, 199-209. doi: 10.1007/978-1-4939-1695-5_16

11. Tague, B. W., \& Mantis, J. (2006). In planta Agrobacteriummediated transformation by vacuum infiltration. In J. Salinas, \& J. J. Sanchez-Serrano (Eds.), Arabidopsis Protocols. Vol. 123. Methods in Molecular Biology (pp. 215-223). (2 $2^{\text {nd }}$ Ed.). Totowa, New Jersey: Humana Press. doi: 10.1385/1-59745-003-0:215

12. Luria, S. E., \& Burrous, J. W. (1957). Hybridization between Escherichia coli and Shigella. J. Bacteriol., 74(4), 461-476.

13. Chauhan, H., \& Khurama, P. (2017). Wheat genetic transformation using mature embryos as explants. Methods Mol. Biol., 1679, 153-210. doi: 10.1007/978-1-4939-7337-8_10

14. Sparks, C. A., Doherty, A., \& Jones, H. D. (2014). Genetic transformation of wheat via Agrobacterium-mediated DNA delivery. Methods Mol. Biol., 1099, 235-250. doi: 10.1007/978-162703-715-0_19

15. Dargahlou, S. A., Uliaie, E. D., \& Bandehagh, A. (2017). Callus induction and plant regeneration from mature embryos of some Iranian wheat (Triticum aestivum L.) genotypes. J. Bio. Env. Sci., 10(5), 275-283.

16. Karami, 0. (2008). Factors affecting Agrobacterium-mediated transformation of plants. Transgenic Plant J., 2(2), 127-137.

17. Ishida, Y., Tsunashima, M., Hiei, Y., \& Komari, T. (2015). Wheat (Triticum aestivum L.) transformation using immature embryos. Methods Mol. Biol., 1223, 189-198. doi: 10.1007/978-1-49391695-5_15 
18. Wu, H., Sparks, C., Amoah, B., \& Jones, H. D. (2003). Factors influencing successful Agrobacterium-mediated genetic transformation of wheat. Plant Cell Rep., 21(7), 659-568. doi: 10.1007/s00299-002-0564-7

19. Murashige, T., \& Skoog, F. (1962). A revised medium for rapid growth and bio assays with tobacco tissue cultures. Phys. Plant., 15(3), 473-497. doi: 10.1111/j.1399-3054.1962. tb08052.x

20. Manfroi, E., Yamazaki-Lau, E., Grando, M. F., \& Roesler, E. A. (2015). Acetosyringone, $\mathrm{pH}$ and temperature effects on transient genetic transformation of immature embryos of Brazilian wheat genotypes by Agrobacterium tumefaciens. Genet. Mol. Biol., 38(4), 470-476. doi: 10.1590/S1415-475738420150026

21. Aramrak, A., Kidwell, K. K., Steber, C. M., \& Burke, I. C. (2015). Molecular and phylogenetic characterization of the homoeologous EPSP Synthase genes of allohexaploid wheat, Triticum aestivum (L.). BMC Genomics., 16, 844. doi: 10.1186/s12864015-2084-1

22. Bliffeld, M., Mundy, J., Potrykus, I., \& FuKtterer, J. (1999). Genetic engineering of wheat for increased resistance to powdery mildew disease. Theor. Appl. Genet., 98, 1079-1086. doi: $10.1007 / \mathrm{s} 001220051170$

23. Ma, B., Mayfield, M. B., Gold, M. H. (2001). The Green fluorescent protein gene functions as a reporter of gene expression in Phanerochaete chrysosporium. Appl. Env. Micr., 67(2), 948-955. doi: 10.1128/AEM.67.2.948-955.2001

24. Jordan, M. C. (2000). Green fluorescent protein as a visual marker for wheat transformation. Plant Cell Rep., 19(11), 1069-1075. doi: 10.1007/s002990000246

25. Kyriienko, A. V., Parii, M. F., Kuchuk, M. V., Symonenko, Yu. V., \& Shcherbak, N. L. (2019). Optimisation of callusogenesis induction conditions for Triticum spelta $\mathrm{L}$. and $T$. aestivum $\mathrm{L}$. Plant Var. Stud. Prot., 15(3), 259-266. doi: 10.21498/25181017.15.3.2019.181084

26. Jefferson, R. (1987). Assaying chimeric genes in plants: the GUS gene fusion system. Plant Mol. Biol. Rep., 5, 387-405. doi: 10.1007/bf02667740

27. Béziat, C., Kleine-Vehn, J., \& Feraru, E. (2017). Histochemical staining of $\beta$-Glucuronidase and its spatial quantification. Methods Mol. Biol., 1497, 73-80. doi: 10.1007/978-1-49396469-7_8

28. Porebski, S., Bailey, L. G., \& Baum, B. R. (1997). Modification of a CTAB DNA extraction protocol for plants containing high polysaccharide and polyphenol components. Plant Mol. Biol. Rep., 15(1), 8-15. doi: 10.1007/BF02772108

29. Gouranga, U., Moutushi, S., \& Amitava, R. (2015). In vitro callus induction and plant regeneration of rice (Oryza sativa L.) var. 'Sita', 'Rupali' and 'Swarna Masuri'. Asian J. Plant Sci. Res., 5(5), 24-27.

30. Kronbak, R., Ingvardsen, R. C., Madsen, K. C., \& Gregersen, L. P. (2014). A novel approach to the generation of seamless constructs for plant transformation. Plant Methods., 10, 10. doi: 10.1186/1746-4811-10-10

31. De Riso, V., Raniello, R., Maumus, F. et al. (2009). Gene silencing in the marine diatom Phaeodactylum tricornutum. Nucleic Acids Res., 37(14), e96. doi: 10.1093/nar/gkp448

\section{Використана література}

1. Hamada H., Liu Y., Nagira Y. et al. Biolistic-delivery-based transient CRISPR/Cas9 expression enables in planta genome editing in wheat. Sci. Rep. 2018. Vol. 8. 14422. doi: 10.1038/ s41598-018-32714-6

2. Jones H. D., Duherty A., Wu H. Review of methodologies and a protocol for the Agrobacterium-mediated transformation of wheat. Plant Methods. 2005. Vol. 1. 5. doi: 10.1186/1746-4811$1-5$

3. Wu H., Doherty A., Jones H. D. Efficient and rapid Agrobacterium-mediated genetic transformation of durum wheat (Triticum turgidum L. var. durum) using additional virulence genes.
Transgenic Res. 2008. Vol. 17, Iss. 3. P. 425-436. doi: 10.1007/ s11248-007-9116-9

4. Hayta S., Smedley M. A., Demir S. U. et al. An efficient and reproducible Agrobacterium-mediated transformation method for hexaploid wheat (Triticum aestivum L.). Plant Methods. 2019. Vol. 26. 121. doi: 10.1186/s13007-019-0503-z

5. Dale P. J., Marks M. S., Brown M. M. et al. Agroinfection of wheat: inoculation of in vitro grown seedlings and embryos. Plant Sci. 1989. Vol. 63, Iss. 2. P. 237-245. doi: 10.1016/01689452(89)90249-5

6. Dattgonde N., Tiwari S., Sapre S., Gontia-Mishra I. Genetic transformation of oat mediated by Agrobacterium is enhanced with sonication and vacuum infiltration Iranian. Iran J. Biotechnol. 2019. Vol. 17, Iss. 1. e1563. doi: 10.21859/ijb.1563

7. Kumar R., Mamrutha H. M., Kaur A. et al. Optimization of Agrobacterium transformation in spring bread wheat using mature and immature embryos. Mol. Biol. Rep. 2019. Vol. 46, Iss. 2. P. 1845-1853. doi: 10.1007/s11033-019-04637-6

8. Hensel G., Marthe C., Kumlehn J. Agrobactrium-mediated transformation of wheat using immature embryos. Methods Mol. Biol. 2017. Vol. 1679. P. 129-131. doi: 10.1007/978-1-4939-7337-8_8

9. He Y., Jones H. D., Chen S. et al. Agrobacterium-mediated transformation of durum wheat (Triticum turgidum L. var. durum $\mathrm{cV}$ Stewart) with improved efficiency. J. Exp. Bot. 2010. Vol. 61, Iss. 6. P. 1567-1581. doi: 10.1093/jxb/erq035

10. Medvecká E., Harwood W. A. Wheat (Triticum aestivum L.) transformation using mature embryos. Methods Mol. Biol. 2015. Vol. 1223. P. 199-209. doi: 10.1007/978-1-4939-1695-5_16

11. Tague B. W., Mantis J. In planta Agrobacterium-mediated transformation by vacuum infiltration. Arabidopsis Protocols. Vol. 123. Methods in Molecular Biology. Totowa, New Jersey : Humana Press, 2006. P. 215-223. doi: 10.1385/1-59745-003-0:215

12. Luria S. E., Burrous J. W. Hybridization between Escherichia coli and Shigella. J. Bacteriol. 1957. Vol. 74, Iss. 4. P. 461-476

13. Chauhan H., Khurama P. Wheat genetic transformation using mature embryos as explants. Methods Mol. Biol. 2017. Vol. 1679. P. 153-210. doi: 10.1007/978-1-4939-7337-8_10

14. Sparks C. A., Doherty A., Jones H. D. Genetic transformation of wheat via Agrobacterium-mediated DNA delivery. Methods Mol. Biol. 2014. Vol. 1099. P. 235-250. doi: 10.1007/978-1-62703715-0_19

15. Dargahlou S. A., Uliaie E. D., Bandehagh A. Callus induction and plant regeneration from mature embryos of some Iranian wheat (Triticum aestivum L.) genotypes. J. Bio. Env. Sci. 2017. Vol. 10, Iss. 5. P. 275-283.

16. Karami 0. Factors affecting Agrobacterium-mediated transformation of plants. Transgenic Plant J. 2008. Vol. 2, Iss. 2. P. 127-137.

17. Ishida Y., Tsunashima M., Hiei Y., Komari T. Wheat (Triticum aestivum L.) transformation using immature embryos. Methods Mol. Biol. 2015. Vol. 1223. P. 189-198. doi: 10.1007/978-14939-1695-5_15

18. Wu H., Sparks C., Amoah B., Jones H. D. Factors influencing successful Agrobacterium-mediated genetic transformation of wheat. Plant Cell Rep. 2003. Vol. 21, Iss. 7. P. 659-568. doi: 10.1007/s00299-002-0564-7

19. Murashige T., Skoog F. A revised medium for rapid growth and bio assays with tobacco tissue cultures. Phys. Plant. 1962. Vol. 15, Iss. 3. P. 473-497. doi: 10.1111/j.1399-3054.1962. tb08052.x

20. Manfroi E., Yamazaki-Lau E., Grando M. F., Roesler E. A. Acetosyringone, $\mathrm{pH}$ and temperature effects on transient genetic transformation of immature embryos of Brazilian wheat genotypes by Agrobacterium tumefaciens. Genet. Mol. Biol. 2015. Vol. 38, Iss. 4. P. 470-476. doi: 10.1590/S1415-475738420150026

21. Aramrak A., Kidwell K. K., Steber C. M., Burke I. C. Molecular and phylogenetic characterization of the homoeologous EPSP Synthase genes of allohexaploid wheat, Triticum aestivum (L.). BMC Genomics. 2015. Vol. 16. 844. doi: 10.1186/s12864-0152084-1 
22. Bliffeld M., Mundy J., Potrykus I., FuKtterer J. Genetic engineering of wheat for increased resistance to powdery mildew disease. Theor Appl. Genet. 1999. Vol. 98. P. 1079-1086. doi: 10.1007/s001220051170

23. Ma B., Mayfield M. B., Gold M. H. The Green fluorescent protein gene functions as a reporter of gene expression in Phanerochaete chrysosporium. Appl. Env. Micr. 2001. Vol. 67, Iss. 2. P. 948-955. doi: 10.1128/AEM.67.2.948-955.2001

24. Jordan M. C. Green fluorescent protein as a visual marker for wheat transformation. Plant Cell Rep. 2000. Vol. 19, Iss. 11. P. 1069-1075. doi: 10.1007/s002990000246

25. Кирієнко А. В., Парій М. Ф., Кучук М. В., Симоненко Ю. В., Щербак Н. Л. Розроблення ефективної методики індукції калюсогенезу зі зрілих зародків Triticum spelta L. та T. aestivum L. Plant Var. Stud. Prot. 2019. T. 15, № 3. C. 259-266. doi: 10.21498/2518-1017.15.3.2019.181084

26. Jefferson R. Assaying chimeric genes in plants: the GUS gene fusion system. Plant Mol. Biol. Rep. 1987. Vol. 5. P. 387-405. doi: $10.1007 /$ bf02667740
27. Béziat C., Kleine-Vehn J., Feraru E. Histochemical staining of $\beta$-Glucuronidase and its spatial quantification. Methods Mol. Biol. 2017. Vol. 1497. P. 73-80. doi: 10.1007/978-1-49396469-7_8

28. Porebski S., Bailey L. G., Baum B. R. Modification of a CTAB DNA extraction protocol for plants containing high polysaccharide and polyphenol components. Plant Mol. Biol. Rep. 1997. Vol. 15, Iss. 1. P. 8-15. doi: 10.1007/BF02772108

29. Gouranga U., Moutushi S., Amitava R. In vitro callus induction and plant regeneration of rice (Oryza sativa L.) var. 'Sita', 'Rupali' and 'Swarna Masuri'. Asian J. Plant Sci. Res. 2015. Vol. 5, Iss. 5. P. 24-27

30. Kronbak R., Ingvardsen R. C., Madsen K. C., Gregersen L. P. A novel approach to the generation of seamless constructs for plant transformation. Plant Methods. 2014. Vol. 10. 10 doi: 10.1186/1746-4811-10-10

31. De Riso V., Raniello R., Maumus F. et al. Gene silencing in the marine diatom Phaeodactylum tricornutum. Nucleic Acids Res. 2009. Vol. 37, Iss. 14, e96. doi: 10.1093/nar/gkp448

\section{УДК 602.7:57.085.2:633.111.5}

Кирієнко А. В. ${ }^{1,{ }^{2}}$, Кучук М. В. ${ }^{1}$, Щербак Н. Л. ${ }^{1}$, Парій М. Ф. ${ }^{2,3}$, Симоненко Ю. В. ${ }^{1,2}$ Експресія генів gus та gfp у амфідиплоїдної пшениці спельти (Triticum spelta L.) після Agrobacterium-опосередкованої трансформаціï. Plant Varieties Studying and Protection. 2020.T. 16, № 1. С. 103-113. https://doi.org/10.21498/25181017.16.1.2020.201377

${ }^{1}$ Iнститут клітинної біології та генетичної інженерії нАн України, вул. Академіка Заболотного, 148б, м. Київ, 03143, Україна, *e-mail: anastasija.kirienko@gmail.com

${ }^{2}$ Всеукраїнський науковий інститут селекції, вул. Васильківська, 30, м. Київ, 03022, Україна

${ }^{3}$ Національний університет біоресурсів та природокористування України, вул. Героїв Оборони, 15, м. Київ, 03041, Україна

Мета. Дослідити експресію генів gus та gfp в калюсних експлантах амфідиплоїдної пшениці спельти (Triticum spelta L.) після Agrobacterium-опосередкованої генетичної трансформації. Методи. Для трансформації було обрано сорт пшениці спельти озимої 'Європа'. Як експланти використовували калюси, отримані зі зрілих зародків. Прекультивацію калюсів здійснювали на живильному середовищі МС (Мурасіге-Скуга), доповненому 2 мг/л 2,4-Д (2,4-дихлорфеноксиоцтова кислота) та 10 мг/л нітратом срібла. Для генетичної трансформації використовували Agrobacterium tumefaciens Conn., штам GV3101, та генетичну конструкцію з репортерними генами gus (ген бета-глюкуронідази ( $\beta$-glucuronidase)) та gfp (ген зеленого флюоресцентного білка (Green Fluorescent Protein, GFP)). Калюси трансформували шляхом інокуляції 3 агробактеріями та вакуумною інфільтрацією. Далі їх ко-культивували на середовищі МС із 2 мг/л 2,4-Д та $10 \mathrm{мr/л} \mathrm{AgNO}_{3^{\prime}}$ але без антибіотиків. Експресію гена gus перевіряли за допомогою гістохімічного, а гена gfp візуального аналізу (флуоресценція білка GFP в УФ світлі). Рівні експресії генів gfp та gus оцінювали за допомогою програмного забезпечення ImajeJ. Інтеграцію генів gfp та gus в геном спельти перевіряли методом ПлР.
Результати. Генетична трансформація калюсних експлантів спельти шляхом їхньої інокуляції в живильному середовищі з агробактеріями та вакуумною інфільтрацією відбувалась 3 різною частотою. Рівень експресії гена gus за вакуумної інфільтрації становив 4,66 $\pm 0,74 \%$, за інокуляції - 4,00 $\pm 0,91 \%$; а гена gfp за вакуумної інфільтрації - 3,66 0,74\%, за інокуляції - 4,66 $\pm 1,39 \%$. Рівень експресії гена gfp був вищим у разі використання інокуляції 3 агробактеріями, а гена gus - при вакуумній інфільтрації. За допомогою ПЛР-аналізу було підтверджено інтеграцію генів gfp та gus в геном калюсів спельти. Довжина ПЛР продукту із праймерами до гена gus становила 240 п. н., а до гена $g f p-717$ п. н. Висновки. Використання методів вакуумної інфільтрації та інокуляції для генетичної трансформації спельти дали різні результати. Частота генетичної трансформації коливалась від 3,66 до 4,66\%. Agrobacterium-опосередкована генетична трансформація амфідиплоїдної пшениці спельти дозволяє дослідити експресію репортерних генів gus та $g f p$ за використання калюсних експлантів, отриманих із зрілих зародків.

Ключові слова: Triticum spelta L.; спельта; калюсогенез; ген gus; ген gfр; генетична трансформація. 
УДК 602.7:57.085.2:633.111.5

Кириенко А. В. ${ }^{1,{ }^{*}}$, Кучук М. В. ${ }^{1}$, Щербак Н. Л. ${ }^{1}$, Парий М. Ф. ${ }^{2,3}$, Симоненко Ю. В. ${ }^{1,2}$ Экспрессия генов gus и gfp у амфидиплоидной пшеницы спельты (Triticum spelta L.) после Agrobacterium-опосредованной трансформации // Plant Varieties Studying and Protection. 2020. T. 16, № 1. С. 103-113. https://doi.org/10.21498/25181017.16.1.2020.201377

${ }^{1}$ Институт клеточной биологии и генетической инженерии НАН Украины, ул. Академика Заболотного, 1486, г. Киев, 03143, украина, ”e-mail: anastasija.kirienko@gmail.com

${ }^{2}$ Всеукраинский научный институт селекции, ул. Васильковская, 30, г. Киев, 03022, Украина

${ }^{3}$ Национальный университет биоресурсов и природопользования Украины, Украина, 03041, г. Киев, ул. Героев Обороны, 15

Цель. Исследовать экспрессию генов gus и gfp в каллюсных эксплантах амфидиплоидной пшеницы спельты (Triticum spelta L.) после Agrobacterium-опосредованной генетической трансформации. Методы. Для трансформации был выбран сорт пшеницы спельты озимой 'Европа'. В качестве эксплантов использовали каллюсы, полученные из зрелых зародышей. Для прекультивации каллюсов использовали питательную среду МС (Мурасиге-Скуга), дополненную 2 мг/л 2,4-Д (2,4-дихлорфеноксиуксусная кислота) и 10 мг/л нитратом серебра. Для генетической трансформации использовали Agrobacterium tumefaciens Conn., штамм GV3101, и генетическую конструкцию, содержащую репортерные гены gus (ген бета-глюкуронидазы) и $g f p$ (ген зеленого флюоресцентного белка GFP). Каллюсы трансформировали путем инокуляции с агробактериями и вакуумной инфильтрацией. Далее их ко-культивировали на среде МС с 2 мг/л 2,4-Д и 10 мг/л $\mathrm{AgNO}_{3^{\prime}}$ но без антибиотиков. Экспрессию гена gus проверяли с помощью гистохимического анализа, а гена gfp - визуального (флуоресценция белка GFP в UV свете). Уровни экспрессии генов gfp и gus оценивали с помощью программного обеспечения ImajeJ. Интеграцию генов gfp и gus в геном спельты проверяли методом ПЦР. Результаты. Генетическая транс- формация каллюсных эксплантов спельты путём их инокуляции в питательной среде с агробактериями и вакуумной инфильтрацией происходила с разной частотой. Уровень экспрессии гена gus при вакуумной инфильтрации составил 4,66 $\pm 0,74 \%$, а при инокуляции $-4,00 \pm 0,91 \%$, а гена gfp при вакуумной инфильтрации - 3,66 $\pm 0,74 \%$, а при инокуляции $-4,66 \pm 1,39 \%$. Уровень экспресии гена gfp был выше в случае использования инокуляции с агробактериями, а гена gus - при вакуумной инфильтрации. При помощи ПЦР анализа была подтверждена интеграция генов gfp и gus в геном каллюсов спельты. Длина ПЦР продукта с праймерами к гену gus составила 240 п. н., а для гена $g f p$ - 717 п. н. Выводы. Использование методов вакуумной инфильтрации и инокуляции для генетической трансформации спельты дали разные результаты. Частота генетической трансформации колебалась от 3,66 до 4,66\%. Agrobacterium-опосредованная генетическая трансформация амфидиплоидной пшеницы спельты позволяет исследовать экспрессию репортерных генов gus и gfp при использовании каллюсных эксплантов, полученных из зрелых зародышей.

Ключевые слова: Triticum spelta L.; спельта; каллюсогенез; ген gus; ген gfр; генетическая трансформация.

Надійшла / Received 14.02.2020 Погоджено до друку / Accepted 22.03.2020 